\title{
BMP2 promotes chondrocyte proliferation via the Wnt/ $\beta$-catenin signaling pathway
}

\author{
XIHAI LI ${ }^{1}$, JUN PENG ${ }^{1}$, MINGXIA WU ${ }^{1}$, HONGZHI YE ${ }^{1}$, CHUNSONG ZHENG $^{1}$, \\ GUANGWEN WU ${ }^{1}$, HUIFENG XU ${ }^{2}, \mathrm{XUZHENG} \mathrm{CHEN}^{2}$ and XIANXIANG LIU ${ }^{1}$ \\ ${ }^{1}$ Academy of Integrative Medicine, and ${ }^{2}$ Fujian Key Laboratory of Integrative Medicine on \\ Geriatrics, Fujian University of Traditional Chinese Medicine, Fuzhou 350108, P.R. China
}

Received December 21, 2010; Accepted April 8, 2011

DOI: $10.3892 / \mathrm{mmr} .2011 .474$

\begin{abstract}
Bone morphogenetic protein 2 (BMP2), a member of the transforming growth factor- $\beta$ (TGF- $\beta$ ) superfamily, plays a key role in the induction of the differentiation of mesenchymal cells into chondrocytes to form cartilage tissue. However, it is not clear whether BMP2 regulates the proliferation of chondrocytes. In the present study, the effect of BMP2 on the proliferation of chondrocytes and its underlying mechanism was investigated. Chondrocytes isolated from the knee of SD rats were cultured and identified using toluidine blue staining. The second generation chondrocytes were collected and stimulated with or without BMP2 for 48 h. Cell viability was analyzed using the MTT assay. mRNA and protein expression levels of $\beta$-catenin, GSK-3 $\beta$, Dvl1 and Cyclin D1 were detected using real-time RT-PCR and Western blotting, respectively. The cell cycle distribution of the chondrocytes was analyzed by flow cytometry. BMP2 stimulation was found to significantly increase cell viability. In addition, following BMP2 treatment, $\beta$-catenin, Cyclin D1 and Dvl1 expression was significantly increased, whereas GSK-3 $\beta$ expression was significantly decreased. Moreover, the percentage proportion of chondrocytes in the $\mathrm{G} 0 / \mathrm{G} 1$ phase was significantly decreased, whereas that in the $\mathrm{S}$ phase was significantly increased. The results indicate that BMP2 promotes chondrocyte proliferation via the $\mathrm{Wnt} / \beta$-catenin signaling pathway.
\end{abstract}

\section{Introduction}

Osteoarthritis (OA) is a chronic degenerative disease characterized by a basic pathology of cartilage degradation caused by the mutual influence of mechanical and biological factors $(1,2)$. Cartilage is composed of chondroctyes that produce a large amount of extracellular matrix (ECM), including type II

Correspondence to: Professor Xianxiang Liu, Academy of Integrative Medicine, Fujian University of Traditional Chinese Medicine, 1 Huatuo, University Town, Minhou Shangjie, Fuzhou 350108, P.R. China

E-mail: liuxianxiang@163.com

Key words: bone morphogenetic protein 2, chondrocyte, cell cycle, osteoarthritis collagen and proteoglycan (PG) (3). Chondroctyes rapidly respond to changes in the articular microenvironment and regulate the dynamic equilibrium between the degradation and synthesis of the ECM, which is crucial to the maintenance of cartilage function $(4,5)$. Therefore, the functional changes of chondrocytes contribute to the degradation of the articular cartilage, and thus to the pathologenesis of OA.

The maturation process of chondrocytes is closely regulated by a variety of growth factors and environmental conditions $(6,7)$. The $\mathrm{Wnt} / \beta$-catenin signaling pathway is one of the pathways that play an important role in chondrogenesis. The activation of the $\mathrm{Wnt} / \beta$-catenin signaling pathway is initiated when Wnt proteins bind to cell-surface receptors of the Frizzled family, causing the receptors to activate Dishevelled family proteins, such as Dvl1. The activated Dishevelled (DSH) then inhibits a protein complex that is composed of Axin, GSK-3 $\beta$ and the protein APC. The Axin/GSK-3 $\beta /$ APC complex normally promotes the proteolytic degradation of $\beta$-catenin. The inhibition of the Axin/GSK-3 $\beta /$ APC complex results in the accumulation of cytoplasmic $\beta$-catenin, which causes some $\beta$-catenin to translocate into the nucleus, where it interacts with TCF/LEF family transcription factors to promote the expression of specific genes, such as Cyclin D1 $(8,9)$. Cyclin D1 is a positive regulator of G1/S transition and one of the key restriction points in the cell cycle. Therefore, upregulation of Cyclin D1 expression facilitates cell cycle progression and promotes chondrocyte proliferation.

Promoting the proliferation of chondrocytes is an efficient treatment for delaying the progression of cartilage degradation. Previously, we reported that millimeter wave therapy potentially exerts its therapeutic effect on OA by enhancing chondrocyte proliferation (10). Recent studies have focused on growth factors, which have been found to enhance cell proliferation and ECM synthesis in vitro and in vivo. In most studies on the regeneration of transplantation-ready cartilage, recombinant growth factors have been tested individually or in combination. For example, bone morphogenetic protein 2 (BMP2) has been used to promote proliferation and differentiation in primary and subcultured chondrocytes $(11,12)$. The purpose of the present study was to examine whether BMP2 enhances chondrocyte proliferation via the $\mathrm{Wnt} / \beta$-catenin signaling pathway in vitro. The effects of BMP2 on $\beta$-catenin, GSK-3 $\beta$, Dvl1 and Cyclin D1 in chondrocytes were observed 
to explore the mechanisms by which BMP2 regulates the Wnt/ $\beta$-catenin signaling pathway and promotes chondrocyte proliferation at the cellular and molecular levels.

\section{Materials and methods}

Materials and reagents. Dulbecco's modified Eagle's medium (DMEM), fetal bovine serum (FBS) and trypsin-EDTA were purchased from Hyclone (USA). Type II collagenase and 3-(4,5-dimethylthiazol-2-yl)-2,5-diphenyltetrazolium bromide (MTT) were purchased from Sigma-Aldrich (USA). The SYBR fluorescence quantization kit and TRIzol reagent were purchased from Invitrogen Corporation (USA). Rabbit anti-rat $\beta$-catenin, GSK-3 $\beta$, Dv11, Cyclin D1, $\beta$-actin and HRP-IgG secondary goat anti-rabbit antibodies were purchased from Santa Cruz Inc. (USA). The cell cycle assay kit was provided by Becton Dickinson (USA). Primer synthesis was performed by Shanghai Sangon Biological Engineering Technology Services, Ltd. (China). Rat BMP2 was obtained from Beijing Boao Sen Bio-Technology Co., Ltd. (China). Toluidine blue was purchased from Sinopharm Chemical Reagent Co., Ltd. (China).

Animals. Forty-eight 4-week-old male SD specific pathogen-free (SPF) rats were used in this study, including six for primary culture and the identification of chondrocytes and ten for BMP2 stimulation experiments. All experiments were performed in triplicate. The animals were provided by the Shanghai Slack Laboratory Animal Co., with qualified certificate number SCXK (Shanghai) 2007-0005. The treatment of the laboratory animals complied with the Guidelines for the Care and Use of Laboratory Animals 2006, administered by the Ministry of Science and Technology, China (13).

In vitro culture of chondrocytes. The $\mathrm{SD}$ rats were sacrificed and soaked in $75 \%$ alcohol for $5 \mathrm{~min}$. The knee joint was separated and the cartilage removed under sterile conditions. The cartilage was rinsed in PBS and in DMEM three times. The cartilage was sectioned into $1-\mathrm{mm}^{3}$-thick slices and placed in dishes containing $0.2 \%$ type II collagenase, then transferred to a $37^{\circ} \mathrm{C}$ incubator. The supernatant was collected every $60 \mathrm{~min}$ and centrifuged at $800 \mathrm{rpm}$ for $5 \mathrm{~min}$ to obtain the cell pellet. This step was repeated four times. The cells were re-suspended in DMEM complete culture medium (containing $10 \%$ FBS, $50 \mathrm{mg} / \mathrm{l}$ vitamin $\mathrm{C}$ and $100 \mathrm{U} / \mathrm{ml}$ each of ampicillin and streptomycin). The cells were then filtered through 200-mesh stainless steel filters and counted with a blood cell count plate to adjust the concentration of the cell suspension to $2-3 \times 10^{5} \mathrm{ml}$. The cells were seeded in flasks and cultured at $37^{\circ} \mathrm{C}$ in a $5 \% \mathrm{CO}_{2}$ incubator. The primary cultured cells were observed under an inverted microscope and passaged upon reaching $80 \%$ confluence. The second generation of chondrocytes was identified using toluidine blue staining.

Experimental groups. The passage 2 chondrocytes were seeded into 6-well plates at a density of $2.0 \times 10^{5}$ cells/well in $2 \mathrm{ml} 10 \%$ FBS DMEM, cultured for $24 \mathrm{~h}$, then starved for $24 \mathrm{~h}$ in serum-free DMEM medium. The cells were divided into four groups respectively stimulated with BMP2 at concentrations of $0,5,10$ or $20 \mathrm{ng} / \mathrm{ml}$ for 24 or $48 \mathrm{~h}$.
Identification of chondrocytes using toluidine blue staining. The second generation chondrocytes were seeded on cover slips and cultured for $72 \mathrm{~h}$. The cells were washed with PBS, fixed in $4 \%$ neutral formalin for $30 \mathrm{~min}$ and stained with $1 \%$ toluidine blue for $30 \mathrm{~min}$. The slips were rapidly washed in ethanol, dried, placed on slides and sealed. Cell morphology was observed using a phase-contrast microscope (Olympus, Japan). Images were captured at a magnification of x200.

Evaluation of cell viability by MTT assay. Chondrocyte viability was assessed by the MTT colorimetric assay. The passage 2 chondrocytes were seeded into 96-well plates at a density of $1.0 \times 10^{4}$ cells/well in $0.1 \mathrm{ml} 10 \%$ FBS DMEM, cultured for $24 \mathrm{~h}$ and then starved for $24 \mathrm{~h}$ in serum-free DMEM medium. The chondrocytes were then treated with final BMP2 concentrations of $0,5,10$ or $20 \mathrm{ng} / \mathrm{ml}$ for 24 or $48 \mathrm{~h}$. The medium was then removed and the cells were washed once with PBS, then $20 \mu 1$ of $0.5 \%$ MTT solution was added to each well followed by incubation for $4 \mathrm{~h}$ at $37^{\circ} \mathrm{C}$. Subsequently, the MTT solution was removed by aspiration, and $150 \mu 1$ DMSO was added to each well. The 96-well plates were placed on a shaker for $10 \mathrm{~min}$ and the optical density (OD) value of each well was measured at $570 \mathrm{~nm}$ using an ELISA reader (Bio-Tek, Model EXL800, USA).

Real-time PCR detection of $\beta$-catenin, GSK-3 $\beta$ and Dvll mRNA expression in chondrocytes. After treatment of the chondrocytes with BMP2, total RNA was isolated with Trizol reagent according to the manufacturer's instructions. RNA $(1 \mu \mathrm{g})$ was reverse transcribed into cDNA as a template for real-time PCR amplification. The primer sequences and the sizes of the amplicons were as follows: $\beta$-catenin, sense 5'-TCT AGT GCA GCT TCT GGG TT-3', antisense 5'-GAT GGC AGG CTC GGT AAT G-3' (184 bp); GSK-3 $\beta$, sense 5'-CTG CCC TCT TCA ACT TTA CC-3', antisense 5'-TAT TGG TCT GTCCACGGTCT-3' (159 bp); Dvl1, sense 5'-TCAC CGA CTC TAC CAT GTC C-3', antisense 5'-ATA CGA TCT CCC GAA GCA C-3' (258 bp); and, as an internal reference, $\beta$-actin, sense 5'-CGT TGA CAT CCG TAA AGA CC-3', antisense 5'-GGA GCC AGG GCA GTA ATC T-3' (108 bp). The conditions for the real-time PCR amplification reaction were $94^{\circ} \mathrm{C}$ for $4 \mathrm{~min}, 94^{\circ} \mathrm{C}$ for $30 \mathrm{sec}, 52^{\circ} \mathrm{C}$ for $40 \mathrm{sec}$ and $72^{\circ} \mathrm{C}$ for $45 \mathrm{sec}$, for 40 cycles. The dissolution curve was analyzed to determine the specificity of the real-time PCR amplification. The expression levels of the target and reference genes were detected first. To compare differential gene expression among the groups, the $2^{-\Delta \Delta \mathrm{Ct}}$ method was used. The control group was considered the standard sample, and the experimental group was considered the test sample. The calculation method was as follows: i) the reference gene was used to calibrate the target gene expression in the control and experimental groups according to the equation $\Delta \mathrm{Ct}($ standard sample $)=$ target gene $(\mathrm{Mean} \mathrm{Ct})$ - reference gene $\beta$-actin $($ Mean $\mathrm{Ct}$ ), $\Delta \mathrm{Ct}$ (test sample) $=$ target gene $($ Mean $\mathrm{Ct}$ ) - reference gene $\beta$-actin (Mean $\mathrm{Ct}$ ); ii) the normalization of $\Delta \mathrm{Ct}$ in the standard and test samples was calculated as $\Delta \Delta \mathrm{Ct}=$ $\Delta \mathrm{Ct}$ (test sample) $-\Delta \mathrm{Ct}$ (standard sample); iii) differential gene expression was calculated using the formula $2^{-\Delta \Delta C t}$.

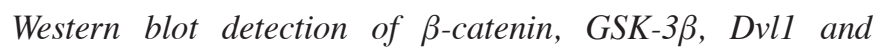
Cyclin D1 protein expression in chondrocytes. Following 

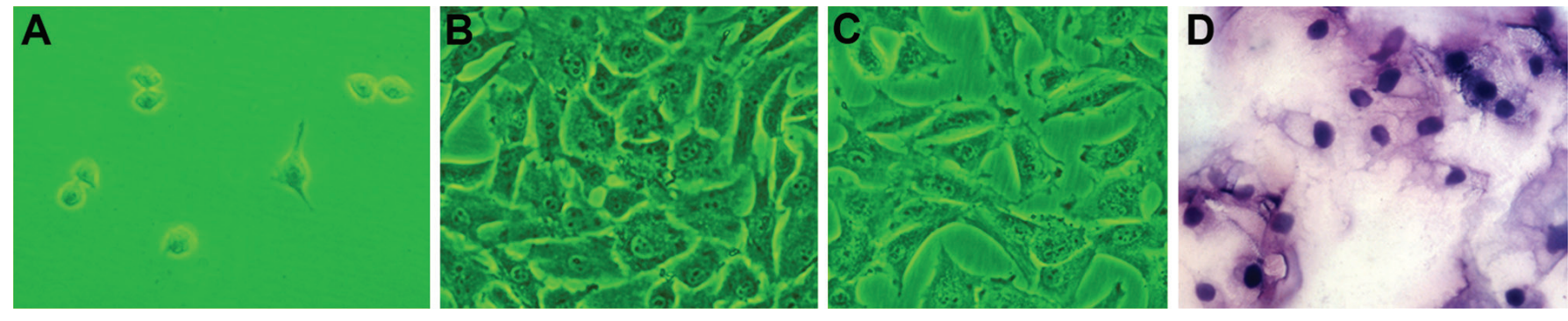

Figure 1. Morphological assessment and identification of chondrocytes (magnification, x200). (A) The initial seeded cells were small and rounded and began to adhere after 24 h. (B) Following 8 days of culture, the cells grew in an irregular 'paving stone' shape. (C) On day 3 , the second generation cells were circular and polygonal-shaped. (D) Toluidine blue-staining results of the second generation chondrocytes on day 3 .

Table I. MTT assay of chondrocyte viability.

\begin{tabular}{lccc}
\hline $\begin{array}{l}\text { BMP2 } \\
(\mathrm{ng} / \mathrm{ml})\end{array}$ & $\begin{array}{c}\text { Before } \\
\text { stimulation }\end{array}$ & $\begin{array}{c}\text { Stimulation } \\
(24 \mathrm{~h})\end{array}$ & $\begin{array}{c}\text { Stimulation } \\
(48 \mathrm{~h})\end{array}$ \\
\hline 0 & $0.27 \pm 0.05$ & $0.34 \pm 0.05$ & $0.42 \pm 0.03$ \\
5 & $0.28 \pm 0.08$ & $0.36 \pm 0.07$ & $0.46 \pm 0.05$ \\
10 & $0.26 \pm 0.06$ & $0.37 \pm 0.06$ & $0.48 \pm 0.04^{\mathrm{a}}$ \\
20 & $0.27 \pm 0.07$ & $0.38 \pm 0.08$ & $0.49 \pm 0.06^{\mathrm{a}}$ \\
\hline
\end{tabular}

${ }^{\text {aP }}<0.05$ compared with BMP2 $0 \mathrm{ng} / \mathrm{ml}$.

BMP2 stimulation, total protein was extracted from the second generation chondrocytes according to the manufacturer's instructions, and the protein concentration was determined using the BCA assay. A 25- $\mu 1$ sample (containing $20 \mu \mathrm{g}$ total protein) was loaded onto a $12 \%$ SDS-polyacrylamide gel, electrophoresed, and then transferred to a PVDF membrane. The membrane was blocked in $3 \%$ bovine serum albumin in Tris-buffered saline (TBS) for $2 \mathrm{~h}$ at room temperature. The primary rabbit antibodies against $\beta$-catenin, GSK-3 $\beta$, Dvl1, Cyclin D1 and $\beta$-actin were added and incubated with the membrane overnight at $4^{\circ} \mathrm{C}$, then the membrane was washed three times with TBS/Tween 20. A secondary antibody against rabbit conjugated to horseradish peroxidase was added to the membrane, followed by incubation at room temperature with gentle agitation for $2 \mathrm{~h}$. Lastly, the membrane was washed three times for $10 \mathrm{~min}$ per wash with TBS/Tween 20. The bands were visualized using an enhanced chemiluminescence (ECL) kit, followed by exposure to X-ray film. The intensity of the bands was analyzed using a Fluor-S gel imaging system. The data are presented as the ratio of the target gene to $\beta$-actin.

Cell cycle analysis of chondrocytes by fluorescence-activated cell sorting (FACS). Following BMP2 stimulation, the passage 2 chondrocytes were digested, collected and re-suspended in PBS. The cell concentration was adjusted to $1 \times 10^{6} \mathrm{ml}$ following centrifugation. Solutions $\mathrm{A}, \mathrm{B}$ and $\mathrm{C}$ were added according to the manufacturer's instructions prior to sample detection. The cells were analyzed using Cellquest software. Modfit software was used to analyze the DNA content and to count the chondrocyte number in the G0/G1, $\mathrm{S}$ and $\mathrm{G} 2 / \mathrm{M}$ phases. The chondrocyte proliferation index was calculated according to the formula: proliferation index $(\mathrm{PI})=$ $(\mathrm{S}+\mathrm{G} 2 / \mathrm{M}) /(\mathrm{G} 0 / \mathrm{G} 1+\mathrm{S}+\mathrm{G} 2 / \mathrm{M})$.
Statistical analysis. SPSS13.0 statistical software was used to process the data, which are presented as the mean \pm standard deviation. Differences among the four groups were compared using one-way analysis of variance (ANOVA), and multiple comparisons were performed with the SNK-q test. $\mathrm{P}<0.05$ was considered statistically significant.

\section{Results}

Morphological observation and identification of chondrocytes. The initial seeded cells were small and rounded, and began to adhere after $24 \mathrm{~h}$. The cells gradually increased in size and spread to form pseudopods (Fig. 1A). After 8 days of culture, the cells grew into clusters and were gradually integrated into a single layer in an irregular 'paving stone' shape (Fig. 1B). The second generation chondrocytes had a regular morphology, uniform size and high proliferation rate (Fig. 1C). After 3 days of culture, toluidine blue-staining induced the formation of purple metachromatic granules within and around the cells. The nuclei were dark blue and round or oval-shaped (Fig. 1D).

Effect of BMP2 on chondrocyte viability. Cell viability was measured using the MTT assay. As shown in Table I, there were no significant differences between the various groups of chondrocytes before or after stimulation for $24 \mathrm{~h}$. However, after stimulation for $48 \mathrm{~h}$, the OD values of the chondrocytes in the groups treated with 10 and $20 \mathrm{ng} / \mathrm{ml}$ BMP2 were significantly higher than those in the $0 \mathrm{ng} / \mathrm{ml}$ group $(\mathrm{P}=0.035$, $\mathrm{P}=0.023)$, suggesting that $\mathrm{BMP} 2$ increases cell viability.

Effect of BMP2 on $\beta$-catenin, GSK-3 $\beta$, Dvll and Cyclin D1 expression. Following BMP2 treatment for $48 \mathrm{~h}$, the mRNA and protein expression of $\beta$-catenin, GSK-3 $\beta$ and Dvl1 was respectively determined by real-time PCR and Western blotting.

The results of real-time PCR for mRNA expression in the chondrocytes are shown in Table II. $\beta$-catenin mRNA was significantly higher in the groups treated with 10 or $20 \mathrm{ng} / \mathrm{ml}$ $\mathrm{BMP} 2$ as compared to the $0 \mathrm{ng} / \mathrm{ml}$ group $(\mathrm{P}=0.029, \mathrm{P}=0.015)$. Dvl1 mRNA was significantly higher in the groups treated with 10 or $20 \mathrm{ng} / \mathrm{ml} \mathrm{BMP} 2$ as compared to the $0 \mathrm{ng} / \mathrm{ml}$ group $(\mathrm{P} \leq 0.001)$ and $5 \mathrm{ng} / \mathrm{ml}$ group $(\mathrm{P}=0.040, \mathrm{P}=0.013)$. GSK-3 $\beta$ mRNA was significantly lower in the $20 \mathrm{ng} / \mathrm{ml} \mathrm{BMP} 2$ group as compared to the $0 \mathrm{~g} / \mathrm{ml}$ group $(\mathrm{P}=0.043)$.

The results of Western blotting for protein expression in the chondrocytes are shown in Table III and Fig. 2. $\beta$-catenin protein was significantly higher in the groups treated with 10 or 
Table II. mRNA expression of $\beta$-catenin, GSK-3 $\beta$ and Dvl1 in chondrocytes.

\begin{tabular}{lccc}
\hline $\begin{array}{l}\text { BMP2 } \\
(\mathrm{ng} / \mathrm{ml})\end{array}$ & $\beta$-catenin & GSK-3 $\beta$ & Dvl1 \\
\hline 0 & $1.00 \pm 0.00$ & $1.00 \pm 0.00$ & $1.00 \pm 0.00$ \\
5 & $1.08 \pm 0.10$ & $0.98 \pm 0.04$ & $1.09 \pm 0.05$ \\
10 & $1.14 \pm 0.11^{\mathrm{b}}$ & $0.97 \pm 0.05$ & $1.19 \pm 0.09^{\mathrm{a}, \mathrm{c}}$ \\
20 & $1.16 \pm 0.14^{\mathrm{b}}$ & $0.96 \pm 0.04^{\mathrm{b}}$ & $1.21 \pm 0.12^{\mathrm{a}, \mathrm{c}}$ \\
\hline
\end{tabular}

${ }^{\mathrm{a}} \mathrm{P}<0.01$; ${ }^{\mathrm{b}} \mathrm{P}<0.05$ compared with BMP2 $0 \mathrm{ng} / \mathrm{ml}$. ${ }^{\mathrm{c}} \mathrm{P}<0.05$ compared with BMP2 $5 \mathrm{ng} / \mathrm{ml}$.

Table III. Protein expression of $\beta$-catenin, GSK-3 $\beta$, Dvl1 and
Cyclin D1 in chondrocytes.

\begin{tabular}{lllll}
\hline $\begin{array}{l}\text { BMP2 } \\
(\mathrm{ng} / \mathrm{ml})\end{array}$ & $\beta$-catenin & GSK-3 $\beta$ & Dvl1 & Cyclin D1 \\
\hline 0 & $0.43 \pm 0.07$ & $0.52 \pm 0.07$ & $0.39 \pm 0.06$ & $0.48 \pm 0.05$ \\
5 & $0.48 \pm 0.07$ & $0.48 \pm 0.07$ & $0.42 \pm 0.05$ & $0.51 \pm 0.06$ \\
10 & $0.58 \pm 0.08^{\text {ad }}$ & $0.43 \pm 0.06^{\mathrm{b}}$ & $0.55 \pm 0.06^{\mathrm{a}, \mathrm{c}}$ & $0.56 \pm 0.05^{\mathrm{b}}$ \\
20 & $0.61 \pm 0.09^{\mathrm{ad}}$ & $0.42 \pm 0.05^{\mathrm{b}}$ & $0.57 \pm 0.07^{\mathrm{a}, \mathrm{c}}$ & $0.57 \pm 0.07^{\mathrm{b}}$
\end{tabular}

${ }^{\mathrm{a}} \mathrm{P}<0.01$; ${ }^{\mathrm{b}} \mathrm{P}<0.05$ compared with BMP2 $0 \mathrm{ng} / \mathrm{ml}$. ${ }^{\mathrm{c}} \mathrm{P}<0.01 ;{ }^{\mathrm{d}} \mathrm{P}<0.05$ compared with BMP2 $5 \mathrm{ng} / \mathrm{ml}$.

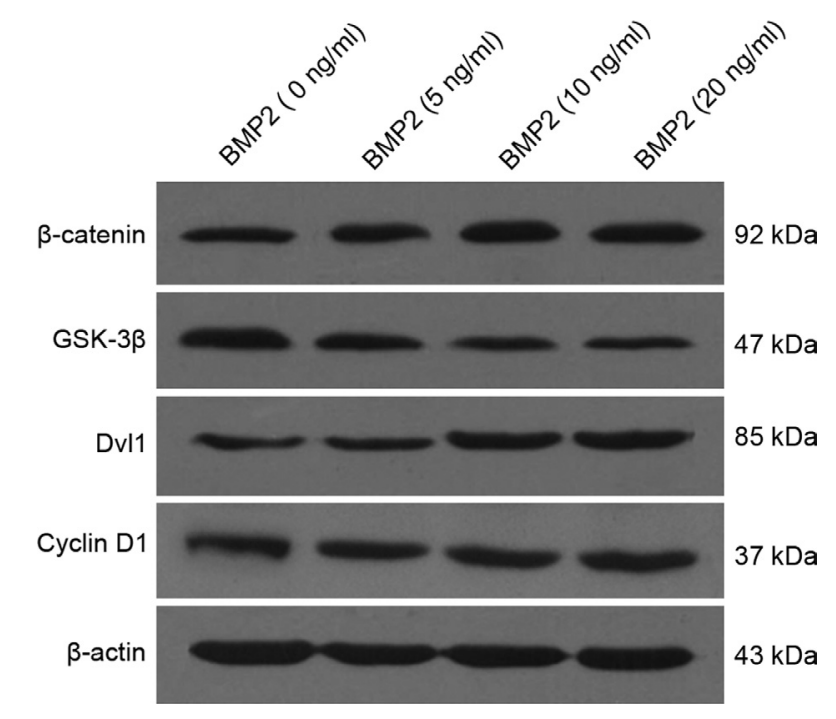

Figure 2. Effect of BMP2 on the expression of $\beta$-catenin, GSK-3 $\beta$, Dvl1 and Cyclin D1 in the chondrocytes. Chondrocytes were stimulated with BMP2 for $48 \mathrm{~h}$ and Western blotting was performed to detect the expression of $\beta$-catenin, GSK-3 $\beta$, Dvl1 and Cyclin D1 proteins in the chondrocytes.

$20 \mathrm{ng} / \mathrm{ml}$ BMP2 as compared to the $0 \mathrm{ng} / \mathrm{ml}$ group ( $\mathrm{P}=0.004$, $\mathrm{P}=0.001)$ and $5 \mathrm{ng} / \mathrm{ml}$ group $(\mathrm{P}=0.032, \mathrm{P}=0.011)$. Dvl1 protein was significantly higher in the groups treated with 10 or $20 \mathrm{ng} /$ $\mathrm{ml} \mathrm{BMP2}$ as compared to the $0 \mathrm{ng} / \mathrm{ml}$ group $(\mathrm{P} \leq 0.001)$ and $5 \mathrm{ng} / \mathrm{ml}$ group $(\mathrm{P} \leq 0.001)$. Cyclin $\mathrm{D} 1$ protein was significantly higher in the groups treated with 10 or $20 \mathrm{ng} / \mathrm{ml} \mathrm{BMP2}$ as
Table IV. Flow cytometry cell cycle analysis of chondrocytes.

\begin{tabular}{|c|c|c|c|c|}
\hline $\begin{array}{l}\text { BMP2 } \\
(\mathrm{ng} / \mathrm{ml})\end{array}$ & $\begin{array}{l}\text { G0/G1 } \\
\text { phase }\end{array}$ & $\begin{array}{c}\mathrm{S} \\
\text { phase }\end{array}$ & $\begin{array}{l}\mathrm{G} 2 / \mathrm{M} \\
\text { phase }\end{array}$ & $\begin{array}{c}\text { Proliferation } \\
\text { (PI) }\end{array}$ \\
\hline \multicolumn{5}{|l|}{ Be. S } \\
\hline 0 & $92.68 \pm 2.83$ & $4.10 \pm 1.89$ & $3.22 \pm 1.21$ & $7.32 \pm 2.83$ \\
\hline 5 & $91.66 \pm 2.29$ & $4.51 \pm 1.51$ & $3.83 \pm 1.32$ & $8.34 \pm 2.29$ \\
\hline 10 & $92.36 \pm 3.17$ & $4.37 \pm 1.85$ & $3.27 \pm 1.51$ & $7.64 \pm 3.17$ \\
\hline 20 & $91.58 \pm 3.13$ & $4.65 \pm 2.28$ & $3.77 \pm 1.45$ & $8.42 \pm 3.13$ \\
\hline \multicolumn{5}{|l|}{ Af. S } \\
\hline 0 & $75.14 \pm 4.85$ & $14.92 \pm 3.36$ & $9.94 \pm 3.24$ & $24.86 \pm 4.85$ \\
\hline 5 & $72.62 \pm 4.48$ & $15.72 \pm 3.47$ & $11.66 \pm 2.51$ & $27.38 \pm 4.4$ \\
\hline 10 & $68.68 \pm 5.29^{a}$ & $19.47 \pm 4.72^{\mathrm{a}}$ & $11.85 \pm 3.04$ & $31.32 \pm 5.2$ \\
\hline 20 & $67.39 \pm 5.19^{a}$ & $19.79 \pm 3.75^{a}$ & $12.82 \pm 2.96$ & $32.61 \pm 5.1$ \\
\hline
\end{tabular}

${ }^{\mathrm{a}} \mathrm{P}<0.05$ compared with BMP2 $0 \mathrm{ng} / \mathrm{ml}$.
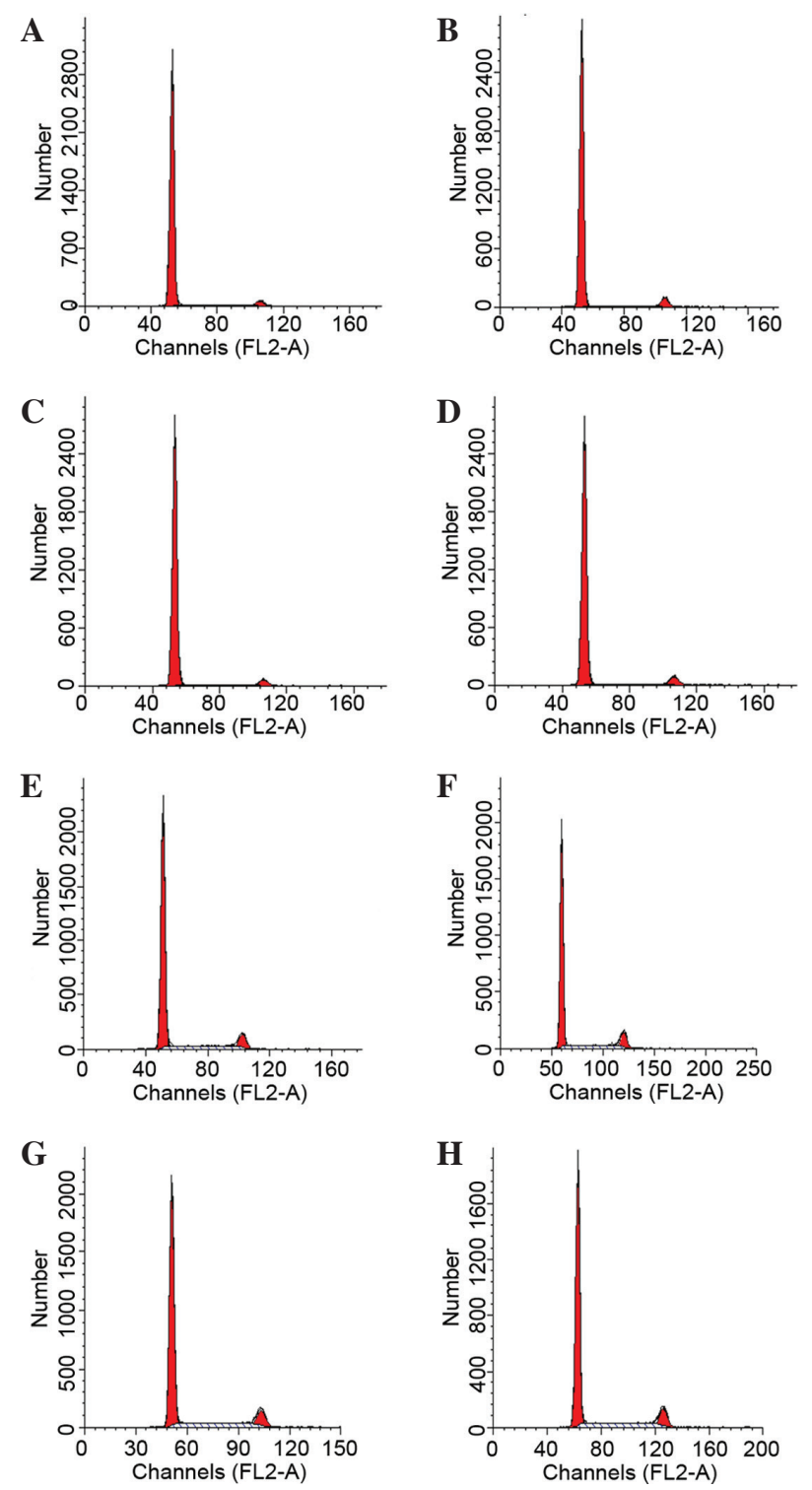

Figure 3. Effect of BMP2 on the cell cycle of the chondrocytes. Cells were starved for $24 \mathrm{~h}$ before stimulation with BMP2 at concentrations of (A) $0 \mathrm{ng} / \mathrm{ml}$, (B) $5 \mathrm{ng} /$ $\mathrm{ml}$, (C) $10 \mathrm{ng} / \mathrm{ml}$, or (D) $20 \mathrm{ng} / \mathrm{ml}$; or for $48 \mathrm{~h}$ at concentrations of (E) $0 \mathrm{ng} / \mathrm{ml}$, (F) $5 \mathrm{ng} / \mathrm{ml}$, (G) $10 \mathrm{ng} / \mathrm{ml}$, or (H) $20 \mathrm{ng} / \mathrm{ml}$. Following BMP2 treatment, the chondrocytes were collected and stained with PI, then subjected to FACS analysis. 
compared to the $0 \mathrm{ng} / \mathrm{ml}$ group ( $\mathrm{P}=0.033, \mathrm{P}=0.012)$. GSK-3 $\beta$ protein was significantly lower in the BMP2 $20 \mathrm{ng} / \mathrm{ml}$ group as compared to the $0 \mathrm{ng} / \mathrm{ml}$ group ( $\mathrm{P}=0.043)$.

Taken together, the data indicate that BMP2 upregulates $\beta$-catenin, Cyclin D1 and Dvl1, and downregulates GSK-3 $\beta$.

Effect of BMP2 on the cell cycle of chondrocytes. The G1/S transition is one of the two main checkpoints used by cells to regulate cell cycle progression and thus cell proliferation. We therefore investigated the effect of BMP2 on G1/S progression in the chondrocytes via PI staining followed by FACS analysis. As shown in Table IV and Fig. 3, the percentage proportion of cells was significantly lower in the G0/G1 phase in the groups treated with 10 or $20 \mathrm{ng} / \mathrm{ml}$ BMP2 as compared to the $0 \mathrm{ng}$ / $\mathrm{ml}$ group $(\mathrm{P}=0.036, \mathrm{P}=0.014)$, and was significantly higher in the $\mathrm{S}$ phase in the groups treated with 10 or $20 \mathrm{ng} / \mathrm{ml} \mathrm{BMP} 2$ as compared to the $0 \mathrm{ng} / \mathrm{ml}$ group $(\mathrm{P}=0.021, \mathrm{P}=0.016)$. The proliferation of cells was therefore significantly increased in the groups treated with 10 or $20 \mathrm{ng} / \mathrm{ml} \mathrm{BMP} 2$ as compared to the $0 \mathrm{ng} / \mathrm{ml}$ group $(\mathrm{P}=0.036, \mathrm{P}=0.014)$, indicating that $\mathrm{BMP} 2$ stimulates chondrocyte proliferation by promoting cell cycle G1/S progression.

\section{Discussion}

The Wnt/ $\beta$-catenin signaling pathway plays a key role during the early stages of cartilage formation $(14,15)$. The Wnt $/ \beta$ catenin pathway regulates the DNA-binding proteins of the TCF/LEF family, mainly in regard to the stability of $\beta$-catenin in the cytoplasm. Intracellular $\beta$-catenin levels are maintained by the balance between degradation and antagonist proteins $(16,17)$. The degradation proteins consist of the APC complex, including GSK-3 $\beta$, Axin and APC. The antagonist proteins

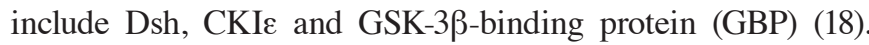
In normal unstimulated cells, the Wnt $/ \beta$-catenin signaling pathway is inactivated. Most $\beta$-catenin is attached to the cytoskeleton through binding to membrane cadherins to mediate the adhesion of the same type of cells. BMP2 is a member of the TGF- $\beta$ superfamily and a multiple regulator of cell growth and differentiation. BMP2 is capable of activating the Wnt/ $\beta$ catenin pathway, upregulating intracellular $\beta$-catenin levels, promoting the translocation of $\beta$-catenin to the nucleus, and activating Cyclin D1 to facilitate chondrocyte cycle progression $(19,20)$. In the present study, chondrocytes were stimulated with BMP2 for 24 or $48 \mathrm{~h}$, and were observed to exhibit significant proliferation ability after $48 \mathrm{~h}$ of stimulation.

BMP2 upregulates the expression of Wnt3a, a secreted ligand for members of the Frizzled family of receptors. This in turn increases the ability of BMP2 to induce the formation of cartilage. Exogenous Wnt3a upregulates $\beta$-catenin and Smad4, both of which synergistically enhance the inducing effect of BMP2. At the same time, BMP2-activated Wnt3a also binds the Frizzled receptor to activate Dvl1. The released GBP binds axin-associated GSK-3 $\beta$, thus inhibiting GSK-3 $\beta$-mediated $\beta$-catenin phosphorylation/degradation. Unphosphorylated $\beta$-catenin accumulates in the cytoplasm and translocates to the nucleus to impair the activity of the complex TCF/LEF family and the GRO and GBP inhibitory proteins. As a consequence, activated Cyclin D1 facilitates the G1/S transition, thus promoting the proliferation of chondro- cytes $(21,22)$. One checkpoint exists in the late $\mathrm{G} 1$ phase, and once the cells pass through this checkpoint, they are no longer dependent on an exogenous stimulation signal for proliferation, thus acquiring the capacity to independently complete the cell cycle (23). The DNA content of the cells reflects the specific processes of cell growth and proliferation. G0 cells are in a quiescent state, G1 cells are in a phase of pre-DNA synthesis, DNA is synthesized in the S phase, and G2 cells become tetraploid. Cells in the G2 phase reserve energy for mitosis (M phase). Our study showed that, following stimulation of chondrocytes with BMP2 for $48 \mathrm{~h}$, the percentage of $\mathrm{G} 0 / \mathrm{G} 1$ cells was reduced while the $\mathrm{S}$ phase cells and the proliferation index were increased. The expression of Dvl1, $\beta$-catenin and Cyclin D1 was significantly increased, while GSK-3 $\beta$ expression was significantly reduced.

In conclusion, BMP2 promotes chondrocyte proliferation by upregulating the expression of Dvl1, $\beta$-catenin and Cyclin D1 and downregulating the expression of GSK-3 $\beta$.

\section{Acknowledgements}

This study was supported by a grant from the Keji Chen Development Foundation for Integrated Traditional and Western Medicine (no. CKJ2008003) and the 2008 Fujian Province Small Creations and Projects (no. 1).

\section{References}

1. Wattanachai T, Yonemitsu I, Kaneko S and Soma K: Functional lateral shift of the mandible effects on the expression of ECM in rat temporomandibular cartilage. Angle Orthod 79: 652-659, 2009.

2. Gentili C and Cancedda R: Cartilage and bone extracellular matrix. Curr Pharm Des 15: 1334-1348, 2009.

3. Brondello JM, Philipot D, Djouad F, Jorgensen C and Noël D: Cellular senescence is a common characteristic shared by preneoplasic and osteo-arthritic tissue. Open Rheumatol J 4: 10-14, 2010.

4. Ko CS, Huang JP, Huang CW and Chu IM: Type II collagenchondroitin sulfate-hyaluronan scaffold cross-linked by genipin for cartilage tissue engineering. J Biosci Bioeng 107: 177-182, 2009.

5. Wada Y, Enjo M, Isogai N, Jacquet R, Lowder E and Landis WJ: Development of bone and cartilage in tissue-engineered human middle phalanx models. Tissue Eng Part A 15: 3765-3778, 2009.

6. Ab-Rahim S, Selvaratnam L and Kamarul T: The effect of TGF-betal and beta-estradiol on glycosaminoglycan and type II collagen distribution in articular chondrocyte cultures. Cell Biol Int 32: 841-847, 2008.

7. Ho ML, Chang JK, Wu SC, Chung YH, Chen $\mathrm{CH}$, Hung SH and Wang GJ: A novel terminal differentiation model of human articular chondrocytes in three-dimensional cultures mimicking chondrocytic changes in osteoarthritis. Cell Biol Int 30: 288-294, 2006.

8. Kerkhof JM, Uitterlinden AG, Valdes AM, et al: Radiographic osteoarthritis at three joint sites and FRZB, LRP5, and LRP6 polymorphisms in two population-based cohorts. Osteoarthritis Cartilage 16: 1141-1149, 2008.

9. Corr M: Wnt-beta-catenin signaling in the pathogenesis of osteoarthritis. Nat Clin Pract Rheumatol 4: 550-556, 2008.

10. Li X, Du M, Liu X, Chen W, Wu M, Lin J and Wu G : Millimeter wave treatment promotes chondrocyte proliferation by up-regulating the expression of cyclin-dependent kinase 2 and cyclin A. Int J Mol Med 26: 77-84, 2010.

11. Ando K, Imai S, Isoya E, et al: Effect of dynamic compressive loading and its combination with a growth factor on the chondrocytic phenotype of 3-dimensional scaffold-embedded chondrocytes. Acta Orthop 80: 724-733, 2009.

12. Jha AK, Yang W, Kirn-Safran CB, Farach-Carson MC and Jia X: Perlecan domain I-conjugated, hyaluronic acid-based hydrogel particles for enhanced chondrogenic differentiation via BMP-2 release. Biomaterials 30: 6964-6975, 2009. 
13. Guidance Suggestions for the Care and Use of Laboratory Animals 2006. The Ministry of Science and Technology of the People's Republic of China, 2006.

14. Vogt S, Wexel G, Tischer T, et al: The influence of the stable expression of BMP2 in fibrin clots on the remodelling and repair of osteochondral defects. Biomaterials 30: 2385-2392, 2009.

15. Mrugala D, Dossat N, Ringe J, et al: Gene expression profile of multipotent mesenchymal stromal cells: identification of pathways common to TGFbeta3/BMP2-induced chondrogenesis. Cloning Stem Cells 11: 61-76, 2009.

16. Zhu M, Tang D, Wu Q, et al: Activation of beta-catenin signaling in articular cartilage cells leads to osteoarthritis-like phenotype in adult beta-catenin conditional activation mice. J Bone Miner Res 24: 12-21, 2009.

17. Chun JS, Oh H, Yang S and Park M: Wnt signaling in cartilage development and degeneration. BMB Rep 41: 485-494, 2008.

18. Imai K, Morikawa M, D'Armiento J, Matsumoto H, Komiya K and Okada Y: Differential expression of WNTs and FRPs in the synovium of rheumatoid arthritis and osteoarthritis. Biochem Biophys Res Commun 345: 1615-1620, 2006.
19. Kawasaki Y, Kugimiya F, Chikuda H, et al: Phosphorylation of GSK-3beta by cGMP-dependent protein kinase II promotes hypertrophic differentiation of murine chondrocytes. J Clin Invest 118: 2506-2515, 2008.

20. Chen T, Li M, Ding Y, et al: Identification of zinc-finger BED domain-containing 3 (Zbed3) as a novel Axin-interacting protein that activates Wnt/beta-catenin signaling. J Biol Chem 284: 6683-6689, 2009.

21. Cong F, Schweizer L and Varmus H: Casein kinase Iepsilon modulates the signaling specificities of dishevelled. Mol Cell Biol 24: 2000-2011, 2004.

22. Yuasa T, Otani T, Koike T, Iwamoto M and Enomoto-Iwamoto M: Wnt/beta-catenin signaling stimulates matrix catabolic genes and activity in articular cartilage cells: its possible role in joint degeneration. Lab Invest 88: 264-274, 2008.

23. Hwang SG, Song SM, Kim JR, Park CS, Song WK and Chun JS: Regulation of type II collagen expression by cyclin-dependent kinase 6, cyclin D1, and p21 in articular cartilage chondrocytes. IUBMB Life 59: 90-98, 2007. 